ISSN: 2224-0616

Int. J. Agril. Res. Innov. \& Tech. 6 (1): 47-57, J une, 2016

Available online at http://www.ijarit.webs.com

\title{
RAPD ANALYSIS OF Sclerotium rolfsii ISOLATES CAUSING COLLAR ROT OF EGGPLANT AND TOMATO
}

\author{
N. Parvin', M. Bilkiss', J. Nahar'2, M.K. Siddiqua ${ }^{3}$ and M.B. Meah*
}

Received 09 April 2016, Revised 15 June 2016, Accepted 21 June 2016, Published online 30 June 2016

\begin{abstract}
Eight isolates of Sclerotium rolfsii from four strategically geographical sites of Bangladesh were characterized and their cultural properties like average linear mycelial growth, colony colour, colony consistency, growth pattern and sclerotia formation were studied. Isolates varied in mycelial growth and other growth characteristics and were grouped into three. The highest linear growth was displayed by $\mathrm{S}_{8}$. DNA concentration of eight isolates varied from 1150-7200 ng/ $\mathrm{kl}$. DNA fingerprinting by RAPD prompted the grouping of isolates. Selected 3 primers generated 20 bands with size ranging from 100-1500 bp. Out of the 20 bands, 9 bands (45\%) were polymorphic and 11 bands (55\%) were monomorphic among the eight isolates of Sclerotium rolfsii. The co-efficient of gene differentiation $\left(\mathrm{G}_{\mathrm{st}}\right)$ was 1.000 reflecting the existence of high level of genetic variations among the 8 isolates. The lowest genetic distance and highest inter isolate similarity was found in $S_{1}$ and $S_{2}$ which would be homogeneous. The highest genetic distance and lowest inter isolate similarity found in $\mathrm{S}_{3}, \mathrm{~S}_{7}$ and $\mathrm{S}_{3}, \mathrm{~S}_{8}$ pair which would be most divergent isolates. The cluster analysis also revealed that $S_{3}, S_{7}$ and $S_{8}$ belong to different clusters. All five varieties of eggplant and tomatoes were graded as susceptible when inoculated with eight isolates. Plant mortality $93.33 \%$ was recorded in $\mathrm{S}_{4}, \mathrm{~S}_{6}$ and in $\mathrm{S}_{8}$. Considering the isolate factor the most virulent isolate would be $\mathrm{S}_{8}$ whereas the less virulent isolate would be $\mathrm{S}_{2}$ and $\mathrm{S}_{7}$. Host plant of $\mathrm{S}_{8}$ was tomato collected from Thakurgaon. $\mathrm{S}_{2}$ and $\mathrm{S}_{7}$ were collected from BAU farm and Dinajpur and host plants were lentil and tomato respectively. It is evident that Sclerotium rolfsii from Thakurgaon on host tomato is more virulent.
\end{abstract}

Keywords: Sclerotium rolfsii Isolates, RAPD, Disease Reaction

${ }^{1}$ IPM Lab, Department of Plant Pathology, Bangladesh Agricultural University, Mymensingh, Bangladesh
${ }^{2}$ Department of Genetics and Plant Breeding, Sylhet Agricultural University, Bangladesh
${ }^{3}$ Department of Molecular and Cellular Biology, University of Guelph, Canada
${ }^{*}$ Corresponding author's email: bmeah@ yahoo.com (M.B. Meah)

\section{Introduction}

Sclerotium rolfsii Sacc. is a soil borne plant pathogen causing diseases on a wide range of agricultural and horticultural crops. It has wide geographic diversity and commonly found in the tropics, subtropics and other warm temperate regions especially in the Southern United States, Central and South America, West Indies, Southern European countries bordering the Mediterranean, Africa, India, Japan, Philippines and Hawaii (Aycock, 1966) and in warmer region like Bangladesh (Talukder, 1974; Ahmed and Hossain, 1985).The wide host range, prolific growth and ability to produce persistent sclerotia contribute to the large economic losses associated with this pathogen. It is aggressive in terms of virulence and affects a wide variety of plants, including most vegetables, cereals, legumes, flower and forage plants. Eggplant and tomato are among the common hosts of the fungus. In Asiatic region, eggplant shows more diversity because of many varieties, cultivars, landraces, hybrids, advanced lines and wild races. More than 60 cultivars of eggplant are grown in Bangladesh (Meah et al., 2007). In Bangladesh, eggplant suffers from 12 disease of which collar rot caused by S. rolfsii is one of the most important and damaging diseases. The pathogen attacks the collar zone of the host adjacent to the soil level causing death by disrupting translocation of food from top to root zone. The disease has become a major constraint in successful cultivation of eggplant mainly due to aggressive nature of the pathogen, its soil borne nature and continuous cropping of eggplant in many areas (Begum et al., 1985). The disease foot/ collar rot causes $60-100 \%$ death of eggplants (Siddique et al., 2002).

The cultures of S. rolfsii originating from various plant species and different geographical regions present wide variation in growth rate, morphological characteristics, mycelial compatibility and exhibit genetic variability. However, the cultures of S. rolfsii can be 
identified by the size, color and structure of their sclerotia. The objective of this study was to compare the growth behavior of indigenous fungal strains and to study the morphological and genetic similarities and differences among different fungal strains isolated from various locations of Bangladesh.

Molecular markers are the most valuable tools for the classification of germplasm and in Marker Assisted Selection (MAS). RAPD technique is currently being used for the systematization and understanding of the phylogenetic relationships of the pathogen. The present study was an effort to use RAPD polymorphism as a tool to determine the genetic variation among the isolates of S. rolfsii. We have studied the morphological feature of the fungus. Some variations are found in morphological characteristics. By RAPD analysis, studies on the genetic variation can reveal variability of isolates in molecular level. We can detect which isolate is virulent, which is avirulent among the isolates in their growing location and respective host. The findings will be a document in the research arena. Considering the above facts the present study was, therefore, undertaken to reveal the differences in virulence/aggressiveness among the isolates of S. rolfsii.

\section{Materials and Methods}

The experiments were conducted in the Plant Disease Diagnostic Clinic, Department of Plant Pathology, and at the Biotechnology division of Bangladesh Institute of Nuclear Agriculture. The experiments were performed during J uly 2008 to October 2009. The lab experiment and net house experiment were conducted in completely randomized design (CRD) with three replications.

\section{Studies on morphological characteristics of Sclerotium rolfsii isolates}

Isolates were collected from plants affected by collar rot of eggplant, tomato, spinach and lentil showing symptoms on leaves, stems, fruits and seeds. The isolates were collected from 4 strategic localities in Bangladesh. Finally, eight isolates were identified through microscopic observation and available literatures (Barnett and Hunter, 1972). The PDA media was prepared following the procedure of Tuite (1969).

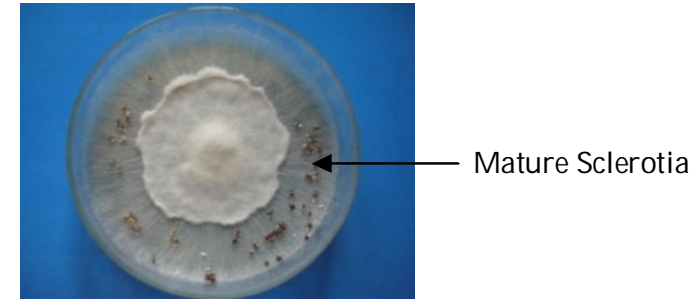

Photograph1. Mature culture of Sclerotium rolfsii

After seven days of incubation $5 \mathrm{~mm}$ disc of mycelial mat from the growing edge of the cultures were transferred to the centre of new potato dextrose agar plate in triplicate for each isolates. Average linear mycelial growth was taken after 24, 48, 72 hours of incubation. Colonies of the isolates were studied for Shape, Colour, Growth habit, Compactness and Initiation of sclerotia formation (photo 1).

\section{Molecular characterization of S. rolfsii}

\section{DNA extraction from S. rolfsii}

For DNA extraction, mycelial cultures of 7 days old raised individually in potato dextrose broth were collected, squeezed in cheesecloth to remove the liquid and then blot with tissue paper. The mycelium was then wrapped in aluminium foil and kept in freezer at $-20^{\circ} \mathrm{C}$ until further use. 8 isolates of S. rolfsii were used for the RAPD. The extraction of total genomic DNA of each isolate of S. rolfsii was made as described by Raeder and Broda (1985).

\section{Confirmation of DNA}

Isolated genomic DNA contains a large amount of RNA and pigments that can usually cause spuriously high estimation of DNA concentration on a spectrophotometer. For this reason, 1\% agarose gels were used for assessing both the quantity and the quality of the genomic DNA and the amount of RNA present. The quality of DNA was measured in Spectrophotometer at $260 \mathrm{~nm}$. The Absorbance reading and DNA concentration varied from (0.023-0.144) $\mathrm{\mu l}$ and (1150-6500) $\mathrm{\mu l}$ respectively. It is necessary to optimize the amount of DNA used in PCR assay to achieve reproducibility and strong signal. Using the above absorbance readings, the original concentrations were determined according to the following formula:

DNA Conc. $(\mathrm{ng} / \mu \mathrm{l})=$ Absorbance $\mathrm{x} \frac{\text { Volume of distilled water }(\mu \mathrm{l})}{\text { Amount of DNA sample }(\mu \mathrm{l})} \times$ Conversion factor $(0.05) \times 1000$

Preparation of working solution of DNA samples

Before PCR, DNA concentrations were adjusted Where,

to $25 \mathrm{ng} / \mu \mathrm{l}$ using the following formula:

$\mathrm{V}_{1}=$ Initial volume of DNA solution $(\mu \mathrm{l})$

$\mathrm{V}_{1} \times \mathrm{S}_{1}=\mathrm{V}_{2} \times \mathrm{S}_{2}$

$\mathrm{S}_{1}=$ Initial DNA concentration $(\mathrm{ng} / \mu \mathrm{l})$

$\mathrm{V}_{2}=$ Final volume of DNA solution $(\mu \mathrm{l})$

$\mathrm{S}_{2}=$ Final DNA concentration $(\mathrm{ng} / \mu \mathrm{l})$

$\mathrm{V}_{2}=\mathrm{V}_{1} \times \mathrm{S}_{1} / \mathrm{S}_{2}$ 


\section{Nethouse experiment for disease reaction}

Three eggplant varieties (Bholanath, Dohazari G and BAUbegun1) and two tomato varieties (Ratan and Udayan) were used in the experiment. Seeds of eggplant were collected from IPM Laboratory, Department of Plant Pathology, Bangladesh Agricultural University, Mymensingh. Seeds of tomatoes were collected from local market of Mymensingh. The seeds were directly sown in the earthen pot filled with soil mixture. Watering was done to maintain the soil moisture.

\section{Preparation of Inocula of Sclerotium rolfsii}

Inocula of the pathogen, Sclerotium rolfsii were prepared through barley culture method (photo 2) (Babar, 1999).

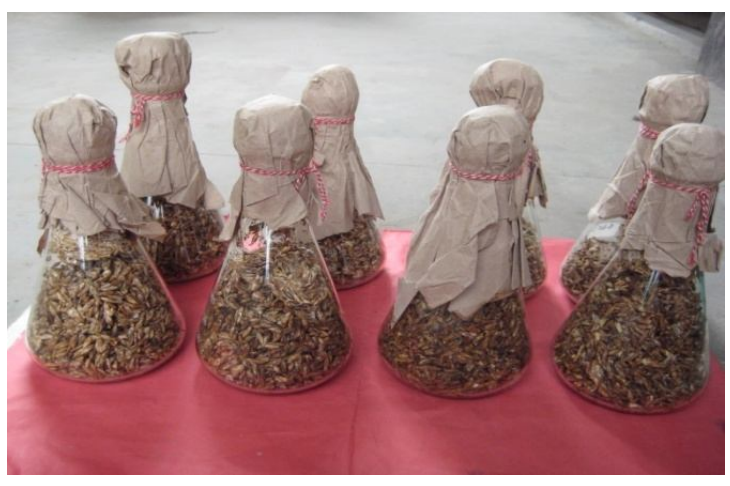

Photograph 2. Barley culture of S. rolfsii (7 days old)

Inoculation of eggplants with the S. rolfsii

Three plants (45 days old) were individually inoculated in each pot in each replication by mixing $10 \mathrm{~g}$ of infested barley grain with soil near plant base and covered with moist cotton (Babar, 1999). Equal number of plants were kept uninoculated as control.
Inoculation was done in the afternoon, cotton was kept moist by adding water as required.

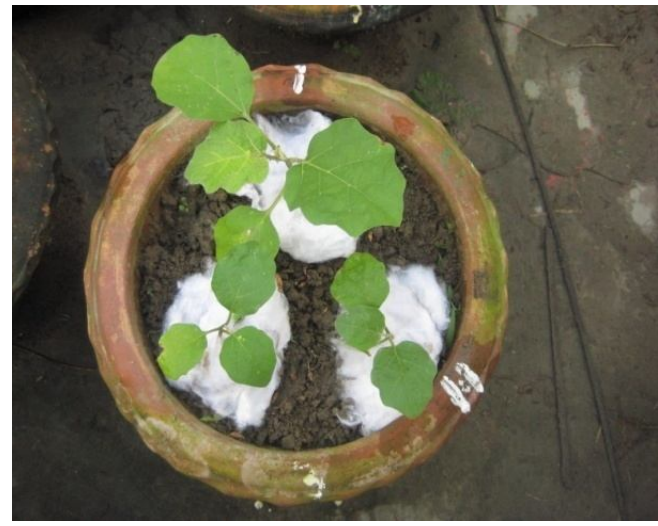

Photograph 3. Wrapping the inoculated collar region of eggplant with moist cotton to create favorable environment for the pathogen

\section{Data Collection}

After inoculation observations were made regularly on the number of plants infected of each variety in each replication, lesion size (in $\mathrm{cm}$ ), variety wise plants reactions as a part of response to infection e.g., reduction of base diameter, reduction in leaf number and number of plants killed.

\section{Assessment of reaction of eggplant varieties to foot/collar rot}

After inoculation, mortality was recorded up to 15 days and expressed in percentage. The tested varieties were placed in various categories of resistance and susceptibility on the basis of mortality percentage using the standard rating scale (1-9) developed by ICRISAT (Nene et al., 1982) (Table 1).

Table 1. Standard rating scale of resistance and susceptibility of plants developed by ICRISAT

\begin{tabular}{lll}
\hline Scale & Mortality (\%) & Reaction \\
\hline 1 & 0 & Resistant (R) \\
$2-3$ & 10 or less & Moderately resistant (MR) \\
$4-5$ & $11-20$ & Tolerant (T) \\
$6-7$ & $21-50$ & Moderately susceptible (MS) \\
$8-9$ & $51-$ above & Susceptible (S) \\
\hline
\end{tabular}

\section{Statistical analysis of data}

Data collected during experimental period were tabulated and analyzed following statistical package MSTAT. Treatment means for disease reaction were compared with Tukey's Honestly Significant difference Test and others were compared with Duncan's Multiple Range Test (DMRT).

\section{Results and Discussion}

Morphological characteristics of S. rolfsii isolates

\section{Mycelial growth}

S. rolfsii exhibited white cottony mycelial growth. The agar media were completely covered by the mycelia at $4^{\text {th }}$ day after inoculation in all the isolates. The highest mycelial growth was observed in $\mathrm{S}_{8}$ (8.633) followed by $\mathrm{S}_{5}, \mathrm{~S}_{7}, \mathrm{~S}_{1}$ and $\mathrm{S}_{4}$. Lowest mycelial growth was observed in $\mathrm{S}_{6}$. $\mathrm{S}_{8}$ 
was collected from tomato from Thakurgaon and $\mathrm{S}_{6}$ was collected from BAU campus and host plant was tomato.

\section{Growth rate}

Highest growth rate was found in $\mathrm{S}_{8}$ and lowest rate was in $\mathrm{S}_{6}$.

\section{Colony colour and shape}

All isolates produced cottony white mycelia and regular shaped colony (Table 2, Photo. 4)

\section{Growth pattern}

In most isolates mycelial growth was fluffy. Dense fluffy rings were produced in isolates $\mathrm{S}_{1}, \mathrm{~S}_{2}$.
Scattered fluffy growth pattern was observed in isolates $\mathrm{S}_{3}, \mathrm{~S}_{4}$ and $\mathrm{S}_{8}$. Mycelial growth was embedded and compact in isolates $\mathrm{S}_{5}$ and $\mathrm{S}_{7}$ (Table 2, photo. 4).

\section{Sclerotia formation}

Sclerotia were formed by the fungus at the edges of the plates from 5 days after inoculation when the agar media were completely covered by the mycelia. The sclerotia were formed first at $S_{1}, S_{2}$ and $S_{7}$. It was 6 days for $S_{8}$ to form sclerotia while it took 7-9 days in isolates $S_{3}, S_{4}, S_{5}$ and $S_{6}$.

Table 2. Colony characters of the eight isolates of Sclerotium rolfsii

\begin{tabular}{|c|c|c|c|c|c|c|}
\hline Isolates & $\begin{array}{l}\text { Place of } \\
\text { collection }\end{array}$ & Host plant & $\begin{array}{l}\text { Colony } \\
\text { colour }\end{array}$ & Shape & Growth pattern & $\begin{array}{l}\text { Initiation of } \\
\text { sclerotia } \\
\text { formation }\end{array}$ \\
\hline $\mathrm{S}_{1}$ & Thakurgaon & Spinach & $\begin{array}{l}\text { Cottony } \\
\text { white }\end{array}$ & Regular & $\begin{array}{l}\text { Fluffy, compact at the } \\
\text { centre }\end{array}$ & 5 \\
\hline $\mathrm{S}_{2}$ & $\begin{array}{l}\text { BINA farm, } \\
\text { Mymensingh }\end{array}$ & Lentil & $\begin{array}{l}\text { Cottony } \\
\text { white }\end{array}$ & Regular & $\begin{array}{l}\text { Fluffy, compact at the } \\
\text { centre }\end{array}$ & 5 \\
\hline $\mathrm{S}_{3}$ & $\begin{array}{l}\text { BINA farm, } \\
\text { Mymensingh }\end{array}$ & Lentil & $\begin{array}{l}\text { Cottony } \\
\text { white }\end{array}$ & Regular & Scatteredly fluffy & 9 \\
\hline $\mathrm{S}_{4}$ & $\begin{array}{l}\text { BAU farm, } \\
\text { Mymensingh }\end{array}$ & Lentil & $\begin{array}{l}\text { Cottony } \\
\text { white }\end{array}$ & Regular & $\begin{array}{l}\text { Fluffy, more fluffy at the } \\
\text { periphery }\end{array}$ & 7 \\
\hline $\mathrm{S}_{5}$ & Ishurdi, Pabna & Lentil & $\begin{array}{l}\text { Cottony } \\
\text { white }\end{array}$ & Regular & $\begin{array}{l}\text { Mostly } \\
\text { embedded,compact }\end{array}$ & 8 \\
\hline $\mathrm{S}_{6}$ & BAU farm & Eggplant & $\begin{array}{l}\text { Cottony } \\
\text { white }\end{array}$ & Regular & $\begin{array}{l}\text { Fluffy, compact at the } \\
\text { centre }\end{array}$ & 9 \\
\hline $\mathrm{S}_{7}$ & Dinajpur & Tomato & $\begin{array}{l}\text { Cottony } \\
\text { white }\end{array}$ & Regular & Embedded, compact & 5 \\
\hline S8 & Thakurgaon & Tomato & $\begin{array}{l}\text { Cottony } \\
\text { white }\end{array}$ & Regular & Fluffy, scatteredly fluffy & 6 \\
\hline
\end{tabular}
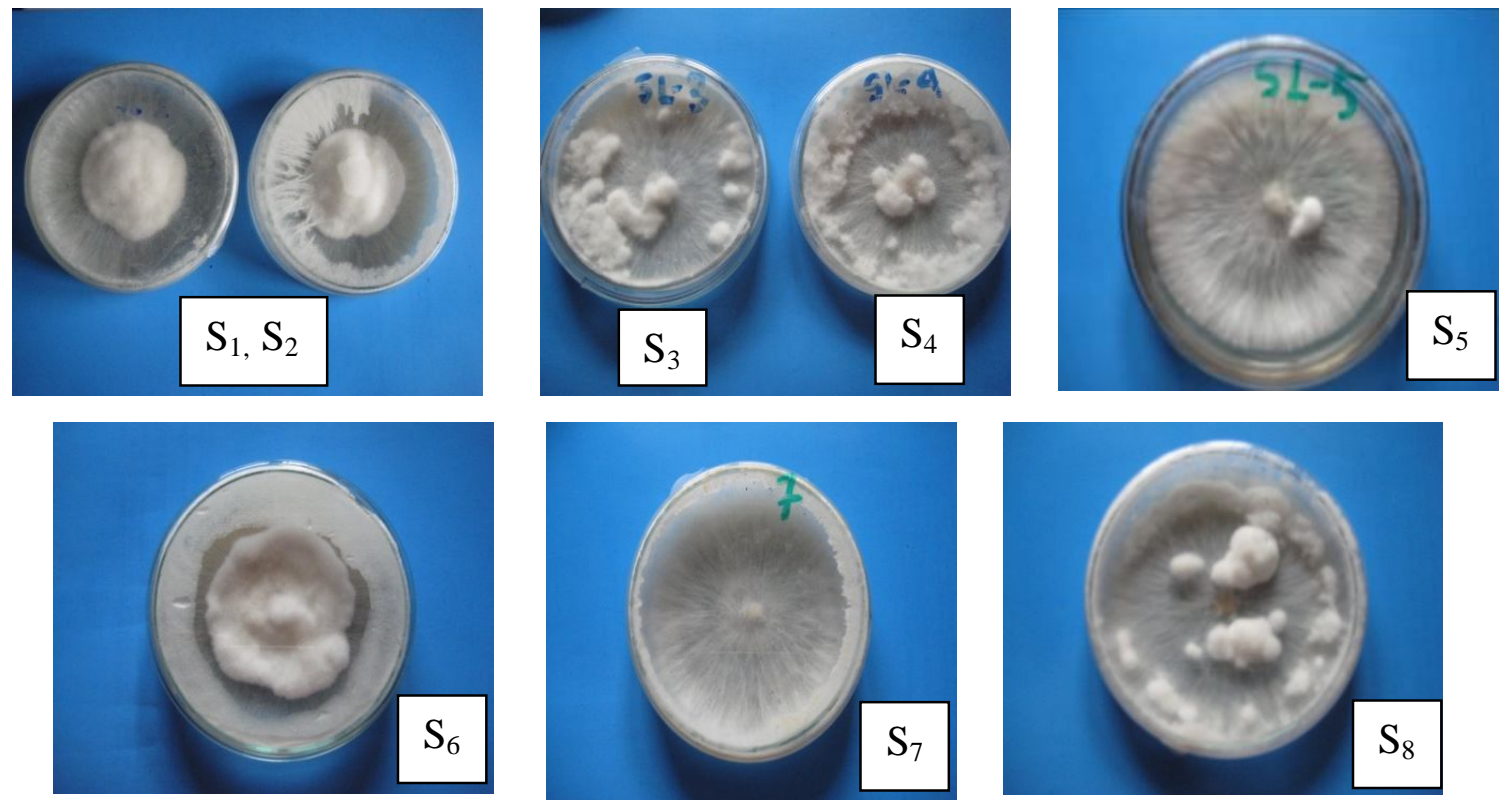

Photograph 4. Growth pattern of S. rolfsii on PDA 


\section{Cultural grouping of isolates}

The isolates were grouped on the basis of growth pattern (Table 3)

Table 3. Grouping of isolate on the basis of growth pattern

\begin{tabular}{ccc}
\hline Group & Isolate & Place of collection \\
\hline 1 & $\mathrm{~S}_{1}$ & Thakurgaon \\
& $\mathrm{S}_{2}$ & BINA farm, Mymensingh \\
2 & $\mathrm{~S}_{6}$ & BAU farm, Mymensingh \\
& $\mathrm{S}_{3}$ & BAU farm, Mymensingh \\
3 & $\mathrm{~S}_{4}$ & BINA farm, Mymensingh \\
& $\mathrm{S}_{8}$ & Thakurgaon \\
& $\mathrm{S}_{5}, \mathrm{~S}_{7}$ & Pabna, Dinajpur \\
\hline
\end{tabular}

\section{Primer selection and RAPD profiles}

Among the 6 primers initially tested OPB-O7, OPC-01 and OPF-15 primers yielded comparatively maximum number of amplification products with high intensity with minimal smearing, good resolution and also clear bands. The number of fragments amplified per primer varied.
Selected 3 primers (OPB-O7, OPC-01 and OPF15) generated 20 bands with size ranging from 100-1500 bp. Out of the 20 bands, 9 bands (45\%) were polymorphic and11 bands (55\%) were monomorphic among the eight isolates of S. rolfsii (Table 4). The banding patterns of the eight isolates of Sclerotium rolfsii using primers OPB-O7, OPC-01 and OPF-15 are shown in Plate 1 (A, B and C).

Table 4. RAPD primers with corresponding bands scored with polymorphic bands observed in eight isolates of S. rolfsii

\begin{tabular}{ccccc}
\hline Primer code & $\begin{array}{c}\text { Sequences } \\
\left(5^{\prime}-3^{\prime}\right)\end{array}$ & $\begin{array}{c}\text { Total } \\
\text { number of } \\
\text { bands } \\
\text { scored }\end{array}$ & $\begin{array}{c}\text { Number of } \\
\text { polymorphic } \\
\text { bands }\end{array}$ & $\begin{array}{c}\text { Proportion of polymorphic } \\
\text { loci (\%) }\end{array}$ \\
\hline OPB-07 & GGTGACGCAG & 6 & 2 & 45 \\
OPC-01 & TTCGAGCCAG & 5 & 1 & \\
OPF-15 & CCAGTACTC & 9 & 6 & \\
\hline Total & & 20 & 9 & \\
\hline Average & & 6.67 & 3 & \\
\hline
\end{tabular}

The primer OPF 15 produced maximum number of bands 9 and OPB 07 produced 6 number of bands whereas OPC 01 generated the least number 5 . On the other hand, the primer OPF 15 amplified maximum number of polymorphic bands 6. The three primers generated 6.67 scorable bands per primer and 3 polymorphic RAPD markers per primer (Table 4). Strong and weak bands were produced in the RAPD reactions. Weak bands result from low homology between the primer and the pairing site on the DNA strand (Thormann et al., 1994). The number of bands per primer varied from 5-9, and polymorphic bands varied from 1-6 with a

\section{Grouping of isolates}

The isolates $\mathrm{S}_{1}, \mathrm{~S}_{2}, \mathrm{~S}_{4}, \mathrm{~S}_{7}$, and $\mathrm{S}_{8}$ formed similar band pattern for primer OPB 07 (Table 5). Based on similarity in band formation 5 isolates were arranged in group 1. The isolates $\mathrm{S}_{3}$ and $\mathrm{S}_{5}$ formed similar band pattern were arranged in group 2. S6 formed another group (Plate 2). For primer OPC 01 the isolates $\mathrm{S}_{1}, \mathrm{~S}_{2}, \mathrm{~S}_{3}, \mathrm{~S}_{4}, \mathrm{~S}_{6}$ and $\mathrm{S}_{7}$ formed similar band pattern were arranged in group 1 (Table 6, Plate 3). $\mathrm{S}_{5}$ and $\mathrm{S}_{8}$ formed similar band pattern belongs to group 2 . The isolates didn't show any similar band in case of primer OPF 15. mean of 3.

Table 5. Grouping of isolates for primer OPB 07

\begin{tabular}{ccc}
\hline Similar band & Lane & Group \\
\hline $\mathrm{S}_{1}, \mathrm{~S}_{2}, \mathrm{~S}_{4}, \mathrm{~S}_{7}$, and $\mathrm{S}_{8}$ & 1 & 1 \\
$\mathrm{~S}_{3}, \mathrm{~S}_{5}$ & 2 & 2 \\
$\mathrm{~S}_{6}$ & 3 & 3 \\
\hline
\end{tabular}

Table 6. Grouping of isolates for primer OPC 01

\begin{tabular}{ccc}
\hline Similar band & Lane & Group \\
\hline $\mathrm{S}_{1}, \mathrm{~S}_{2}, \mathrm{~S}_{3}, \mathrm{~S}_{4}, \mathrm{~S}_{6}, \mathrm{~S}_{7}$ & 1 & 1 \\
$\mathrm{~S}_{5}, \mathrm{~S}_{8}$ & 2 & 2 \\
\hline
\end{tabular}



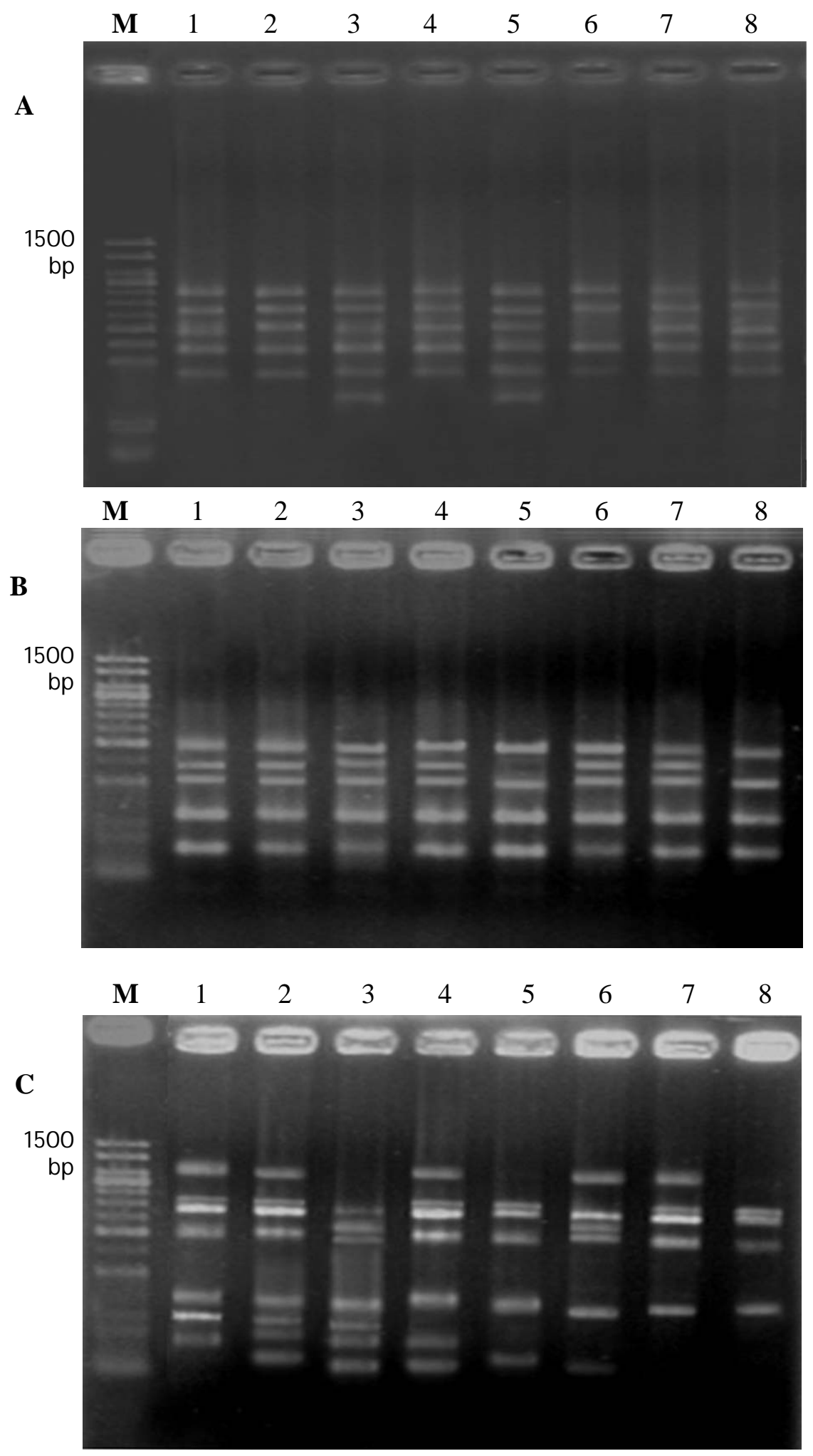

Plate 1. RAPD profile of 8 different accession of S. rolfsii using primer OPB 07 (A), OPC-01 (B), and OPF-15 (C). Lane1- $\mathrm{S}_{1}$, Lane 2: $\mathrm{S}_{2}$, Lane3:S $\mathrm{S}_{3}$ Lane 4: $\mathrm{S}_{4}$, Lane 5: $\mathrm{S}_{5}$, Lane 6: $\mathrm{S}_{6}$, Lane7: $\mathrm{S}_{7}$ and Lane 8: $\mathrm{S}_{8}$ 


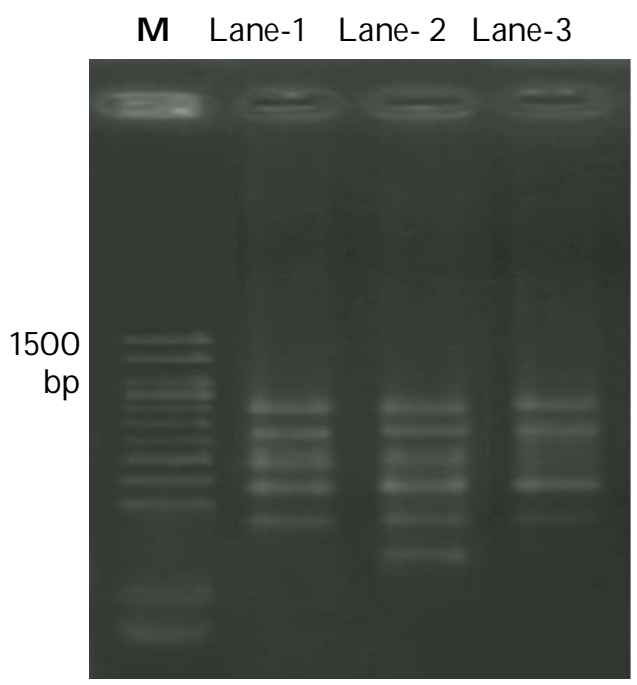

Plate 2. RAPD profiles of OPB 07.

Lane 1: Group1 $\left(\mathrm{S}_{1}, \mathrm{~S}_{2}, \mathrm{~S}_{4}, \mathrm{~S}_{7}\right.$ and $\left.\mathrm{S}_{8}\right)$

Lane 2: Group $2\left(\mathrm{~S}_{3}, \mathrm{~S}_{5}\right)$

Lane 3: Group $3\left(\mathrm{~S}_{6}\right)$

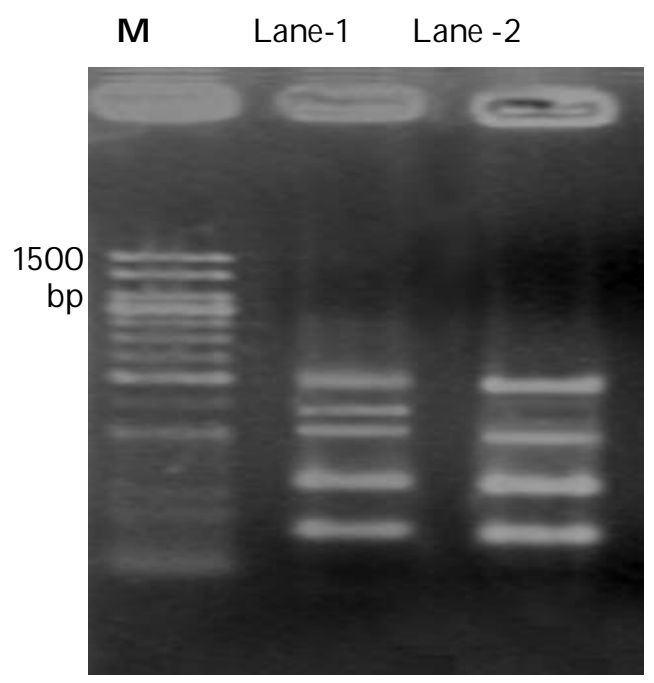

Plate 3. RAPD profiles of OPC 01.

Lane 1: Group1 $\left(\mathrm{S}_{1}, \mathrm{~S}_{2}, \mathrm{~S}_{3}, \mathrm{~S}_{4}, \mathrm{~S}_{6}\right.$ and $\left.\mathrm{S}_{7}\right)$

Lane 2: Group $2\left(\mathrm{~S}_{5}, \mathrm{~S}_{8}\right)$

\section{Inter isolate-similarity indices}

Isolates showing higher inter-variety similarity and lower frequency of polymorphic loci are likely to have less heterozygosity. The highest inter islolate similarity indices $\left(\mathrm{S}_{\mathrm{i}}\right)$ value were found in $\mathrm{S}_{1} \mathrm{Vs}_{2}$ and $\mathrm{S}_{2} \mathrm{Vs} \mathrm{S}_{4}(97.77 \%)$. The lowest inter isolate similarity was found in $\mathrm{S}_{3}$ and $\mathrm{S}_{8}(78.10 \%)$.

\section{Gene flow and co-efficient of gene differentiation}

Nei's analysis of gene diversity (h) in subdivided populations estimated the gene flow $\left(\mathrm{N}_{\mathrm{m}}\right)$ value of 0.0000. Hardy-Weinberg expectation of average heterozygosity in subpopulation $\left(\mathrm{H}_{\mathrm{t}}\right)$ was
0.1812 , whereas obtained heterozygosity $\left(\mathrm{H}_{\mathrm{S}}\right)$ was 0.0000 . Locus OPB07-3, OPB07-6, OPC01-01, OPF15-1, OPF15-2, OPF15-4, OPF15-7, OPF15-8, and OPF15-9 (Gst = 1.000) generated higher level of co-efficient of gene differentiation.

\section{Genetic distance and genetic identity}

The values of pair-wise comparisons of Nei's (1972) genetic distance (D) between isolates were computed from combined data for the 3 primers, ranged 0.0513 to 0.4308.Comparatively higher genetic distance was observed between $S_{3}$ vs. $S_{7}$ (0.4308). The lowest genetic distance (0.0513) was found in $S_{1}, S_{2}$ and $S_{2}, S_{4}$ pairs. Considering the genetic distance values, the results indicated 
that the isolates were genetically different from each other.

\section{Dendrogram}

Dendrogram based on Nei's (1972) genetic distance using Unweighted Pair Group Method of Arithmetic Means (UPGMA) indicated segregation of the 8 isolates of $\mathrm{S}$. rolfsii into two main clusters: $\mathrm{S}_{1}, \mathrm{~S}_{2}, \mathrm{~S}_{4}, \mathrm{~S}_{5}, \mathrm{~S}_{7}$, and $\mathrm{S}_{8}$ grouped into cluster 2 and $S_{3}$ and $S_{6}$ grouped in cluster 1 (Fig. 1). Isolates $S_{3}$ (lentil) and $S_{6}$ (eggplant) were collected from BINA and BAU farm, respectively. $85.64 \%$ similarity was obtained between two isolates.

Cluster 2 was stratified into two-sub cluster. $\mathrm{S}_{5}$ and $\mathrm{S}_{8}$ formed sub cluster 1, which showed $85.85 \%$ similarity while $\mathrm{S}_{1}, \mathrm{~S}_{2}, \mathrm{~S}_{4}$ and $\mathrm{S}_{7}$ formed subcluser-2 with the similarity range of 92.30$97.77 \%$. Again, among the isolates of sub cluster $2, S_{1}, S_{2}$ and $S_{4}$ formed sub sub cluster 1 with the similarity range of $90.47-97.77 \%$ and $S_{7}$ alone belonged to sub sub cluster 2 , which was isolated from Tomato from Dinajpur. $\mathrm{S}_{2}$ and $\mathrm{S}_{4}$ were collected from BINA and BAU farm respectively and host plant was lentil whereas $S_{1}$ collected from eggplant from Thakurgaon. Further, the isolates of sub sub cluster 1 were divided into two groups. $S_{1}$ and $S_{2}$, belonged to group 1 while $S_{4}$ formed group 2 which was collected from lentil from BAU farm. $\mathrm{S}_{5}$ and $\mathrm{S}_{8}$ contained subcluster 1 , which was collected from different host plants and different geographical regions. The host plant of $\mathrm{S}_{5}$ and $\mathrm{S}_{8}$ was lentil and tomato respectively and location was Ishurdi and Thakurgaon. In this study, it is found that several isolates were collected from same host and same region but they are not placed in the same group. The host of $S_{2}, S_{3}$ and $S_{4}$ and is lentil and location was BAU campus $\left(\mathrm{S}_{2}\right.$ and $\mathrm{S}_{3}$ from BINA farm, $\mathrm{S}_{4}$ from BAU). $S_{2}$ and $S_{4}$ belonged to sub sub cluster 1 but in different group whereas $S_{3}$ occupied cluster 2 . There is another controversy that $S_{3}$ (host: lentil) and $\mathrm{S}_{6}$ (host: eggplant) belonged to same group , although they were collected from different host plants. Isolates $S_{2}$ and $S_{3}$ had the same host and same location but they are placed in different clusters.

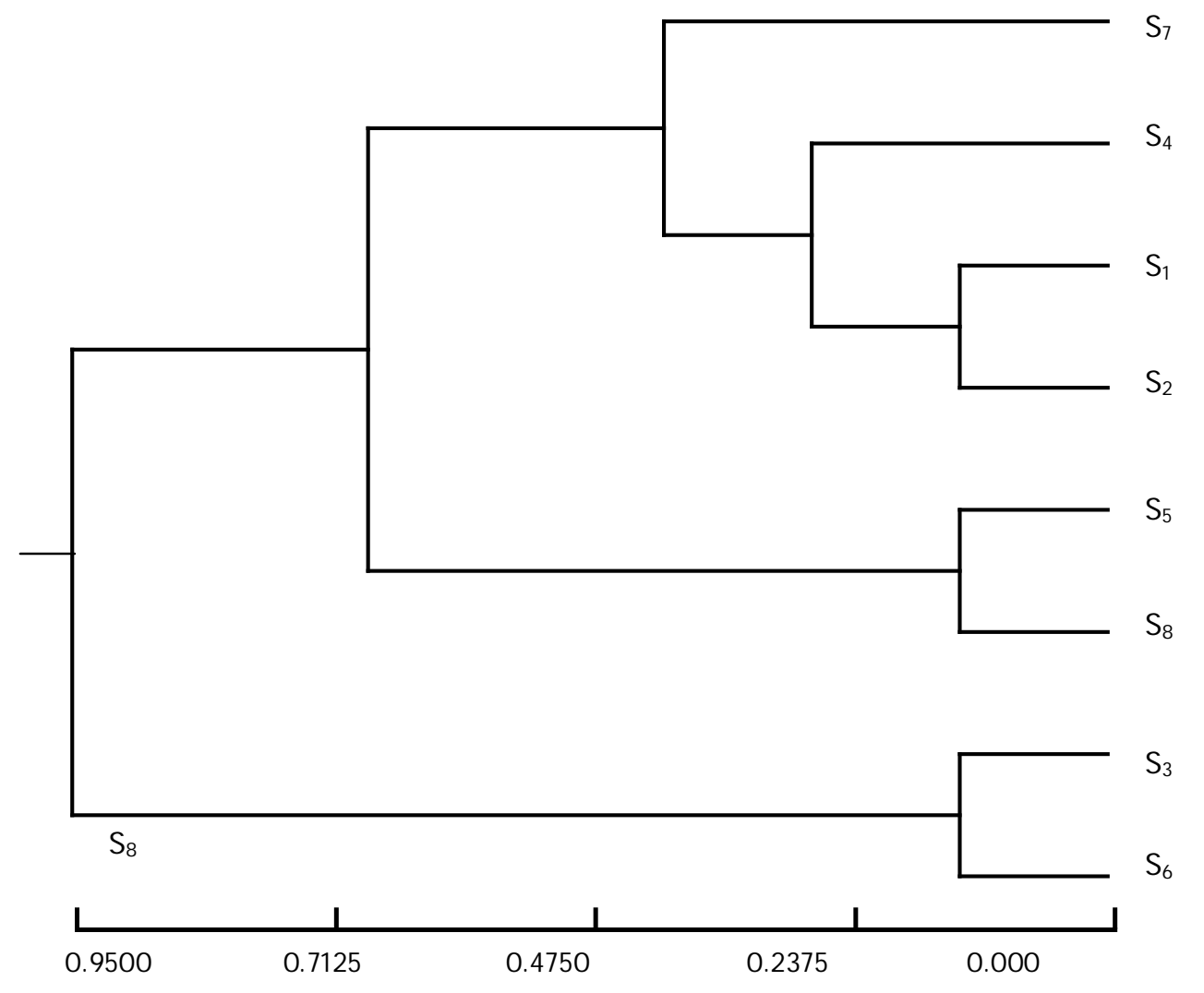

Fig. 1. UPGMA Dendrogram based on Nei's (1972) genetic distance summarizing the data on differentiation among 8 isolates of S. rolfsii 


\section{Development of foot/collar rot sy mptoms on inoculated eggplant}

One day after inoculation of the plants with the barley culture of the S. rolfsii white mycelial mat was observed on soil surface near the plant base. On the second day, white mycelial mat was formed which advanced rapidly towards plant base. Plants were attacked just below the soil surface and were completely girdled. Symptoms as expressed by the plants due to foot/collar rot were exhibited through development of lesions resulting characteristics foot/collar rot of the plants, thus enhancing wilting, yellowing and leaf fall, ultimately killing the plants in susceptible variety (photo 5.a-d).
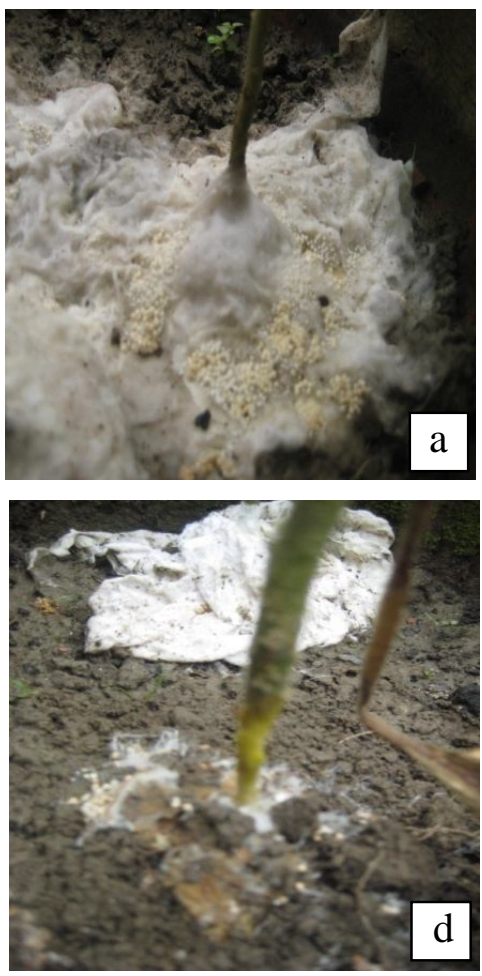

As this experiment was conducted on five different brinjal and tomato varieties so lesion size was different on variety to variety and their reaction to collar rot was variable. The environmental condition like temperature (air and soil), humidity during the inoculation were favourable for the growth and development of the pathogen. Inoculation was done on October 7 when the mean air and soil temperature recorded as 29.0 and $30.4^{\circ} \mathrm{C}$ respectively and average humidity was $89 \%$. The soil temperature and humidity of last 10 days ranged from $28.5-31.3^{\circ} \mathrm{C}$ and $81-89 \%$ respectively. Temperature and humidity have been reported to have influence upon infectivity of S. rolfsii (Treggi, 1956; Palakshappa et al., 1989; Islam, 2008; Siddique et al., 2002).
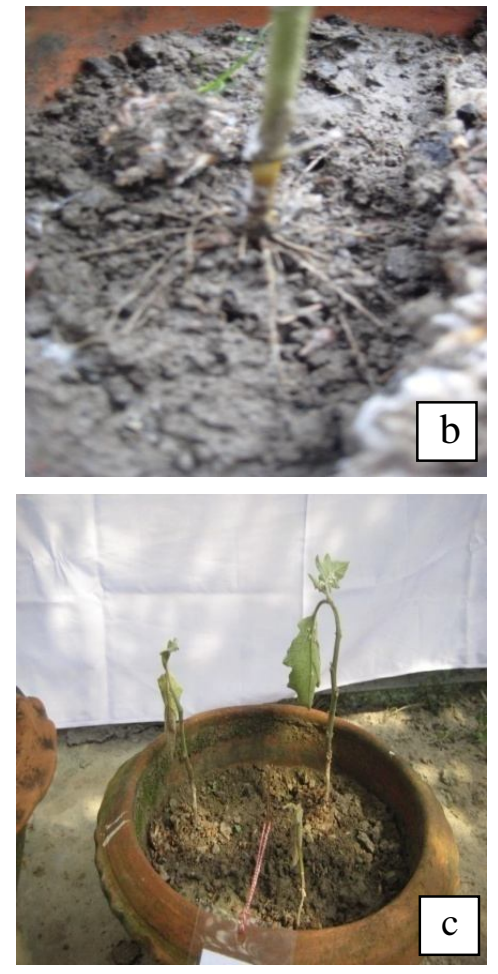

Photograph 5. Symptoms of collar rot of eggplant

a) whitish Sclerotia above cotton pad

b) rotting of plant base

c) wilting of plant

d) plant base become narrow due to progressive lesion Effect of collar rot infection on eggplant
and tomato

There were five test varieties, all were infected.

\section{Lesion size}

The foot/ collar rot symptoms were manifested by lesion developed at collar zone of plants. The lesion size was significantly different in variety to variety. The variety Udayan produced the largest lesion, which was $3.02 \mathrm{~cm}$ that indicated its susceptibility to foot/collar rot disease whereas

the variety BAU Begun1 produced the smallest lesion which was $1.32 \mathrm{~cm}$ (Table 7).

\section{Percent reduction in base diameter}

Base diameter and leaf number of tested varieties were reduced due to foot rot as compared with uninoculated check. Percent plant reduction in base diameter differed significantly among the varieties. Highest reduction in base diameter was recorded in the variety Ratan $14.30 \%$ and lowest in the variety Bholanath (IPM lab-9) which was $11.60 \%$ (Table 7). 


\section{Percent reduction in leaf number Percent Plant mortality and reaction of eggplant}

Percent reduction in leaf number was significantly different among the varieties. Reduction in leaf number was highest in the variety Dohazari $\mathrm{G}$ which was $64.67 \%$ and lowest in the variety Bholanath (IPM Lab-9) which was varieties to foot/collar rot

After inoculation, mortality was recorded up to 15 days and expressed in percentage. All the varieties were graded as susceptible (Table 7). $53 \%$ (Table 7).

Table 7. Disease reaction of five crop varieties to S. rolfsii

\begin{tabular}{ccccccc}
\hline \multicolumn{2}{c}{ Test Variety } & $\begin{array}{c}\text { Lesion } \\
\text { size }(\mathrm{cm})\end{array}$ & $\begin{array}{c}\text { Reduction in } \\
\text { leaf number }(\%)\end{array}$ & $\begin{array}{c}\text { Reduction in base } \\
\text { diameter }(\%)\end{array}$ & $\begin{array}{c}\text { \%plant } \\
\text { mortality }\end{array}$ & $\begin{array}{c}\text { Varietal } \\
\text { reaction }\end{array}$ \\
\hline \multirow{2}{*}{ Tomato } & Udayan & $3.02 \mathrm{a}$ & $60.17 \mathrm{ab}$ & $13.57 \mathrm{ab}$ & $62.50 \mathrm{~b}$ & $\mathrm{~S}$ \\
& Ratan & $2.542 \mathrm{a}$ & $56.67 \mathrm{~b}$ & $14.30 \mathrm{a}$ & $75.00 \mathrm{ab}$ & $\mathrm{S}$ \\
& bholanath & $1.783 \mathrm{~b}$ & $53.00 \mathrm{c}$ & $11.60 \mathrm{c}$ & $70.83 \mathrm{~b}$ & $\mathrm{~S}$ \\
\multirow{2}{*}{ Eggplant } & Dohagari G & $1.385 \mathrm{c}$ & $64.67 \mathrm{a}$ & $13.38 \mathrm{c}$ & $95.83 \mathrm{a}$ & $\mathrm{S}$ \\
& BAUBegun ws & $1.320 \mathrm{c}$ & $54.29 \mathrm{c}$ & 12.10 & $79.17 \mathrm{ab}$ & $\mathrm{S}$ \\
$\mathrm{S}(\mathrm{x})$ & & 0.56 & 1.64 & 0.54 & 7.98 & \\
LSD & & 1.585 & 4.626 & 1.508 & 22.48 & \\
\hline Level of significance & 0.05 & 0.01 & 0.01 & 0.01 & \\
\hline
\end{tabular}

Figures in the column having common letter(s) do not differ significantly at $\mathrm{P}=0.05$ or 0.01 as indicated in the columns

\section{Collar rot due to main effect of pathogen isolates}

In this experiment, there were two factors. The disease reaction in two dimensions due to two factors and their interaction effect were observed. Effect of collar rot in respect to pathogen isolate was observed (Table 8). The different parameters were taken into consideration to detect the virulent isolate (S). Considering the lesion size the most virulent isolate was $\mathrm{S}_{8}$ produced the highest lesion $2.58 \mathrm{~cm}$ whereas least virulent isolate was $\mathrm{S}_{7}$ produced lowest lesion $1.10 \mathrm{~cm}$ (Table 8)

Significant differences in percent leaf number reduction with highest in $\mathrm{S}_{8}, \mathrm{~S}_{4}$ and lowest in $\mathrm{S}_{2}$ (31.93\%) indicating the pathogenicity to develop collar rot were recorded. Due to collar rot disease, the base diameter reduced in infected plant at a considerable rate (Table 8). The tops wilted and died rapidly, often the entire root system was destroyed.
Percent base diameter reduction is an important parameter to trace aggressiveness of isolate. The pathogen isolate $\mathrm{S}_{8}$ caused the highest base diameter reduction, which was $15.79 \%$. The lowest value in base diameter reduction was recorded on $\mathrm{S}_{2}(10.42 \%)$.

Percent plant mortality is a vital parameter to reveal disease reaction in case of collar rot disease. After the infection on plant, typical lesion with sclerotia were seen, consequently plant wilted, base diameter reduced ultimately the plants were killed. Eighty percent or above plant mortality were recorded when inoculation was done with $S_{1}, S_{4}, S_{6}$ and $S_{8}$ as such they might be the virulent isolates. Only one isolate caused below fifty percent plant mortality that was $\mathrm{S}_{2}$ with the value of $46.66 \%$ whereas the isolate $\mathrm{S}_{5}$ and $\mathrm{S}_{7}$ caused $73.33 \%$ mortality. Among eight isolates, the least virulent would be $S_{2}$ based on plant mortality (Table 8).

Table 8. Impact of collar rot due to main effect of pathogen isolates of S. rolfsii

\begin{tabular}{|c|c|c|c|c|c|c|}
\hline Isolate & $\begin{array}{l}\text { Geographical } \\
\text { locaton }\end{array}$ & $\begin{array}{l}\text { Host } \\
\text { plant }\end{array}$ & $\begin{array}{c}\text { Lesion } \\
\text { size }(\mathrm{cm})\end{array}$ & $\begin{array}{l}\text { \% reduction } \\
\text { in leaf } \\
\text { number }\end{array}$ & $\begin{array}{l}\text { \% reduction } \\
\text { in base } \\
\text { diameter }\end{array}$ & $\begin{array}{l}\text { \%plant } \\
\text { mortality }\end{array}$ \\
\hline $\mathrm{S}_{1}$ & $\begin{array}{l}\text { Thakurgaon } \\
\text { BINA farm. }\end{array}$ & $\begin{array}{l}\text { Spinach } \\
\text { Lentil }\end{array}$ & $2.203 \mathrm{~b}$ & $60.00 \mathrm{c}$ & $13.43 \mathrm{bc}$ & $80.00 \mathrm{ab}$ \\
\hline $\mathrm{S}_{2}$ & $\begin{array}{l}\text { Mymensingh } \\
\text { BINA farm, }\end{array}$ & Lentil & $1.210 \mathrm{~d}$ & $31.93 \mathrm{e}$ & $10.42 \mathrm{e}$ & $46.67 \mathrm{c}$ \\
\hline $\mathrm{S}_{3}$ & $\begin{array}{l}\text { Mymensingh } \\
\text { BAU farm. }\end{array}$ & Lentil & $1.540 \mathrm{c}$ & $44.33 d$ & $11.29 \mathrm{de}$ & $60.00 \mathrm{bc}$ \\
\hline $\mathrm{S}_{4}$ & Mymensingh & Lentil & $\begin{array}{l}2.327 b \\
2.153 b\end{array}$ & $\begin{array}{c}71.53 \mathrm{ab} \\
77.07 \mathrm{a}\end{array}$ & $\begin{array}{c}14.77 \mathrm{abc} \\
15.23 \mathrm{ab}\end{array}$ & $\begin{array}{l}93.33 \mathrm{a} \\
73.33 \mathrm{abc}\end{array}$ \\
\hline $\begin{array}{l}\mathrm{S}_{5} \\
\mathrm{~S}_{6}\end{array}$ & BAU farm & Eggplant & $2.170 \mathrm{~b}$ & $66.20 \mathrm{~b}$ & $13.13 \mathrm{~cd}$ & 93.33 a \\
\hline $\mathrm{S}_{7}$ & Dinajpur & Tomato & $1.100 \mathrm{~d}$ & $33.60 \mathrm{e}$ & $9.85 \mathrm{e}$ & $73.33 \mathrm{abc}$ \\
\hline $\mathrm{S}_{8}$ & Thakurgaon & Tomato & $2.580 \mathrm{a}$ & $77.40 \mathrm{a}$ & $15.79 \mathrm{a}$ & $\begin{array}{l}93.33 \mathrm{a} \\
8.94\end{array}$ \\
\hline $\begin{array}{l}S(x) \\
\text { LSD }\end{array}$ & & & $\begin{array}{l}0.71 \\
2.004\end{array}$ & $\begin{array}{l}2.08 \\
5.851\end{array}$ & $\begin{array}{l}0.68 \\
1.907\end{array}$ & $\begin{array}{r}8.94 \\
28.43\end{array}$ \\
\hline Level of & ignificance & & 0.01 & 0.01 & 0.01 & 0.01 \\
\hline
\end{tabular}




\section{References}

Ahmed, H.U. and Hossain, M. 1985. Crop disease survey and establishment of a herbarium at BARI. Final report of the project (1982-85). Plant Pathology Division, Bangladesh Agricultural Research Institute (BARI), Joydebpur, Gazipur. $107 \mathrm{p}$.

Aycock, R. 1966. Stem rot and other diseases caused by S. rolfsii. Tech. Bull. No. 174. Agric. Expt. Station, North Carolina State University, Raleigh. 202 p.

Babar, H.M. 1999. Studies on collar rot of sunflower. Ph. D. thesis, Dept. of Plant Pathology, Bangladesh Agricultural University, Mymensingh, Bangladesh. 12-30 pp.

Barnett, H.L. and Hunter, B.B. 1972. Illustrated genera of imperfect fungi. Third ed. Burgess Publishing Company, West Verginia, pp. 165-169.

Begum, S.N., Chowdhury, B.C. and Ahmed, H.U. 1985. Screening of brinjal varieties resistance to Sclerotium rolfsii. Abstract of papers of 1st National Plant Path Conf. Bangladesh Agricultural Research Institute, Gazipur. Abstract No. 31:12.

Islam, S. 2008. Incidence and severity of foot/collar rot in some varieties of eggplant and control by trichoderma based biopesticide. M.S. thesis. Department of Plant Pathology, Bangladesh Agricultural University, Mymensingh. 2-61 pp.

Meah, M. B., Ahmed, S.A., Islam, M.R., Islam, M.M. and Tusher, M.K. 2007. Eggplants of Bangladesh. IPM laboratory, Dept. of Plant Pathology. Bangladesh Agricultural University, Mymensingh. pp. 1-27.
Nei, M. 1972. Genetic distance between populations. Am. Nat. 106: 283-292.

Nene, Y.L. Haware, M.P. and Reddy, M.O.V. 1982. Chickpea disease resistance screening techniques. Information Bull. No. 10 ICRISAT, Hyderabad, India. $10 \mathrm{p}$.

Palakshappa, M.G., Srikant Kulkarni, Hegde, R. K. and Kulkarni, S. 1989. Effect of organic amendments on the survival ability of Sclerotium rolfsii Sacc, a causal agent of foot rot of betelvine. Mysore J. Agril. Sci. 23(3): 332-336.

Raeder, J. and Broda, P. 1985. Rapid preparation of DNA from filamentous fungi. Letters in Applied Microbiology 1(1): 17-20.

Siddique, M.A.B., Meah, M.B., Siddiqua, M.K., Rahim, M.A. and Haque, M.M. 2002. Response of ten brinjal varieties to foot rot caused by Sclerotium rolfsii. Bangladesh J. Plant Pathol. 18(1/2): 77-81.

Talukder, M.J. 1974. Plant diseases in Bangladesh. Bangladesh J. Agril. Res. 1(1): 1-60.

Treggi, G. 1956. Study of physiological characters of strains of Sclerotium rolfsii isolated from tomatoes and chillis. Ann. Sper. Agr. N. S. 10(5): 1553-1574.

Tuite, J. 1969. Plant pathological methods: Fungi and Bacteria. Minneapolis, Minnesota. USA. Burgess Publishing Company. $239 \mathrm{p}$.

Thormann, C.E., Ferreira, M.E., Camargo, L.E., Tivang, J.G. and Osborn, T.C. 1994. Comparison of RFLP and RAPD markers to estimating genetic relationships within and among cruciferous species. Theor. Appl. Genet. 88: 973-980. 